\title{
Visión de la Nueva Poesía del Brasil
}

\author{
(Trabajo presentado al Concurso \\ Bibliográfico José Toribio Medina, de \\ la "Inter-American Bibliographical and \\ Library Association”.)
}

\author{
P O R T I C O
}

$M E U$ BRASIL

Vinde vêt! Vinde ouvir, homens de terra estranha!

O Brasil de minh'alma, atormentado e aflito,

Cujo nome parece um grito de montanha,

De quebrada em quebrada, acordando o infinito.

Nao é esse Brasil de vida efemera e leviana,

Superficial, anemico, franzino:

E'o Brasil que nascen na minha terra pernambucana,

O Brasil que embalou meus sonhos de menino.

E'o Brasil que, ao canto matinal do acorda-vaqueiro,

Abre os olhos atonitos para a paisagem,

$E$, retesando os musculos de guerreiro,

Olha de frente o sol, como um touro selvagem.

E'o Brasil de cocar e de tacape ao braço,

$O$ ouvido em terra ou a erguet as mãos ameaçadoras,

Para, num salto de jaguar, suster o passo

Das primeiras bandeiras invasoras.

E'o Brasil campeador, o Brasil das guerrilhas

Dos Pampas, que, á feição de centauros, avança

Pelos hanhados $e$ restingas $e$ coxilhas

Peleando no entrevero a pontaços de lança. 
E'o Brasil que depois da luta e da inclemencia,

Volta aos pagos, vencendo a exaustão que o domina,

Para, sorvendo o mate amargo da querencia,

Pôr a guaiaca e coração aos pés da china.

E'o Brasil que através das solidões noturnas

Pelas grotas rasteja e se contorce e freme,

O Brasil-violador das serras e das furnas

Que acorda ao brado de Fernão Dias Pais Leme.

E'o Brasil da Aventura! - o Brasil bandeirante

Rompendo os matagais e escalando as espaldas,

Para rolar barranca abaixo, agonizante,

Em farrapos, com as mãos faiscando de esmeraldas.

E'o Brasil que bebe na concha das mãos crispadas

A agua pura dos rios, se tem sêde,

E dorme, sob a unção das noites estreladas,

Embriagado de luz, ao balanço da rêde.

E'o Brasil de mãos calosas que os campos dilacera

$E$ vê, passada a sarabanda dos temporais,

Num milagre divino, o halito da primavera

Desfraldar a bandeira verde dos canaviais.

E'o Brasil - deus pagão barbaro e forte,

Humilde e bom como ele sempre foi;

O meu Brasil dos pastoris do Norte,

O Brasil do fandango e do bumba meu boi.

O Brasil de alpercata e de chapeu de couro, Agil, nervoso, leal, puro como nasceu, Que tem na sua rêde o ouro do seu tesouro, E tem no seu cavalo a asa que Deus the deu.

Olegatio Matiano. 


\section{PRIMERA PARTE}

Cuando los problemas del intercambio cultural panamericano 1leguen a ese grado de vida y trascendencia que todos anhelamos, una de las preguntas que más insistentemente habrá que formular será, sin duda, ésta: ¿ Por qué, durante tantos y tantos años, los países hispanoparlantes no se preocuparon de estudiar la literatura brasileña con el fervor que ella se merece?

Sin duda, algo se está comenzando a hacer en tal sentido. Sabemos con qué interés se investiga esa literatura en las universidades de los Estados Unidos. Basta, por ejemplo, hojear la revista Books Abroad, órgano de la Universidad de Oklahoma, para tener una idea de la difusión que - lenta pero seguramente - va alcanzando en esos ambientes culturales la literatura del gran país de Ruy Barbosa. Sabemos también que en la Argentina se ha comenzado a publicar una serie de traducciones de novelas brasileñas. Nuestro armonioso lenguaje español parece adquirir nueva vida al expresar - hermanado con algunos dulces vocablos tupíes- ideas y sentimientos de Euclides da Cunha, de Coelho Netto, de Afranio Peixoto, de Herman Lima, reflejando paisajes bravíos y estupendos, ya de la selva, ya del sertão, ya de las ciudades del Brasil, de vida tan intensa y multicolor.

Pero ¿y en el resto del Continente? ¿Qué país puede afirmar que sus revistas, sus periódicos, sus centros de cultura se preocupan de difundir la literatura brasileña, de seguir su desenvolvimiento, de traducir a sus poetas, de publicar biografías? Algunos nobilísimos casos aislados, no son suficientes. Son voces generosas que se pierden en el coro desarmonioso de esta hora trágica que le toca vivir al mundo, hora en que los valores espirituales no ocupan -en la atención general- el puesto primerísimo que les corresponde.

La importancia, la densidad, la riqueza multifacética de la literatura del Brasil requiere, para su estudio, un gran entusiasmo de investigación, de fraternidad. Es, sin duda, demasiado vasta, demasiado lujosa, demasiado compleja. Además, la frecuencia de su carácter nacionalista requiere que el lector esté iniciado en algunos aspectos históricos y geográficos. País de fuerte personalidad, el Brasil posee una literatura muy original, muy propia. $Y$ esto, a la vez que recomienda su difusión, constituye posiblemente una especie de 
valla para cierto sector de lectores, que se desinteresan por obras fuera de su gusto general. Aclaremos: hay en la literatura brasileña producciones de todo carácter, hasta algunas que pueden parecer obra de escritores europeos. Pero lo más valioso de su índice bibliográfico se halla, naturalmente, en los autores que han sabido cavar en la fértil tierra de la brasilidad, de la que han obtenido árboles nuevos, de rica savia y abundante fruto. Así, por ejemplo, Os sertoes de Euclides da Cunha, esa estupenda epopeya, es, por su carácter de obra fundamental, representativa de una época y de una región, comparable -y aun superior en muchos aspectos- al Martín Fierro.

\section{País favorable a la creación poética}

Quizá la belleza, riqueza y variedad de la poesía brasileña tenga su más clara explicación -aparte de la cultura del país y de su diversidad de razas- en la belleza, riqueza y variedad de panoramas y sugestiones estéticas del propio país. Habría, pues, que partir de esta afirmación: es el Brasil uno de los países más favorables para la creación poética. Lo es por la poesía misma de su naturaleza maravillosa, que a la vez que da al artista motivos inagotables de inspiración, lo sumerge en esa atmósfera de ensueño y gracia, tan necesarios al poeta como al místico. $\mathrm{Y}$ en cuanto al ambiente de valoración literaria, hay que recordar que Río de Janeiro es una ciudad cultísima, un importante centro editorial, una metrópolis que recoge y asimila las palpitaciones de la evolución intelectual universal. $\mathrm{Y}$ en Bahía hallamos una ciudad de opt1enta tradición colonial, ya que fué en un tiempo la más populosa urbe de América del Sur. Panoramas magníficos, una grandiosa capital, diversas ciudades de vida grata al espíritu, tesoro de tradiciones indígenas y coloniales, y - sobre todo- esa gracia nueva, esa pureza matinal de un país lleno de optimismo, hacen que el Brasil sea por excelencia un país de la poesía. En una bella página Rubén Darío exaltó la esplendidez del Brasil. Evoquémosla aquí:

Tierra de sol, de poesía y de riqueza, tierra prometida para el trabajo y la energía de los hombres, fué bien llamada Canán por uno de sus preclaros escritores. Todo allí es encanto y lujo de la Naturaleza, de tal manera que los viajeros que por vez primera visitan país tan singular, se diria que sufren como un deslumbramiento, por 
cielos, aguas, bosques, paisajes que se juzgarian ilusorios y en donde se muestra la gracia y potencia del universo. Toda expresión, por hiperbólica que parezca, no sobrepuja a la tealidad, tratándose de este país que contiene tantas cosas enormes, tantas cosas bellas, que parecen de fábula. Una riqueza de minerales imponderable, una variedad infinita de flora y fauna, la bahía más bella y el puerto más bello del mundo y el río Amazonas, el Ecuador movible, inmenso mar dulce, el más grande y admirable de los escenarios soñados para la epopeya.

Y el gran Sarmiento afirmaba:

Los mismos insectos son carbunclos o rubies; las mariposas, plumillas de oro flotantes; pintadas las aves que engalanan penachos y decoraciones fantásticas; verde esmeralda la vegetación; embalsamadas y purpúreas las flores; tangible la luz del cielo; azul cobalto, el aire; doradas a fuego las nubes; roja la tierra y las arenas entre mezcladas de diamantes y rubíes.

\section{Folklore}

$Y$ ahora, luego de estas dos descripciones del ambiente del Brasil, de sus anfiteatros naturales, hablemos de su riqueza folklórica. Para darse una idea de esa riqueza, basta recordar la cantidad de canciones y bailes típicamente brasileros. Dejando a un lado la modinha, de tiempos ya lejanos y en la que sin duda son demasiado visibles las influencias europeas, podemos nombrar como pertenecientes a la música, genuinamente brasilera: el lundú, el maracatú, el catereté, el coco, el batuque, la samba, la macumba, el jongo. De carácter indígena algunas - por ejemplo, el catereté-, otras, afrobrasileñas - el batuque, la macumba- todas ellas, en la multiplicidad de sus matices musicales forman una como orquestación en que se reconoce la brasilidad con sus elementos inseparables: el indígena, el africano, el luso. De esos tres — más el brasileño - surge como de un crisol la expresión auténtica de un país personalísimo. Ahora bien: paralelamente a la música folklórica se ha ido gestando la poesía folklórica, tan opulenta y variada como aquélla, o más. $Y$ entre las notas más interesantes de la poesía culta, se halla esa depuración, esa clarificación de la tonada popular, que expresa de una manera tan honda y sencilla a la vez el alma colectiva. Es, en el plano poético, 
lo que en el musical han hecho en el Brasil artistas de la jerarquía de Francisco Braga, Alberto Nepomuceno, Haeckel Tavares o el formidable Villalobos.

La opulencia del folklore brasileño viene de tiempos inmemoriales. Los aborígenes dejaron poemas muy tiernos y hermosos. Por ello, siempre que los misioneros supieron recurrir a la sugestión y seducción del canto, les fué fácil catequizar a los indios. Como acontece con todas las razas aborígenes de América en sus relaciones con los europeos, la mayor parte de las cantigas autóctonas se perdió. Pero algo queda recogido ya por el francés Montaigne, ya por los alemanes Spix y Martius, ya por los brasileños Couto de Magalhaes y Barbosa Rodrigues. ¡Cuán poética aquella costumbre de los indios tupinambás, al permitir que los poetas de tribus enemigas atravesaran sus campos, sin molestarlos, testimoniando así el alto valor que daban a la poesía y al canto!

Afranio Peixoto puso en lindos versos portugueses esta estrofa recogida por Montaigne, y que yo, a mi vez, diré en español, como una muestra del sutil lirismo de las trovas indígenas del Brasil:

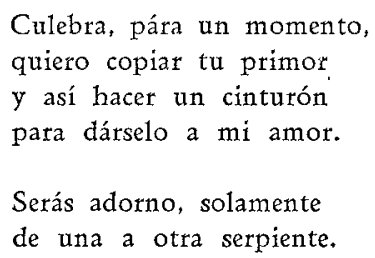

\section{Estitización}

Quizá más que ninguna otra arte, es la poesía la que mejor vive en las zonas de la estilización. Más que la pintura y la escultura, la poesía, por su propia jerarquía de ensueño, pide - como su hermana la música- esa labor descubridora, que depura y afina la expresión. $\mathrm{Y}$ que al depurarla y afinarla, al fijarla en sus valores esenciales, condensa su valor humano, su esencia anímica, contrariando así aquella precipitada afirmación de Ortega y Gasset al considerar que "el arte moderno se deshumaniza al estilizarse". Todo lo contrario. $Y$ una prueba de ello la encontramos en los más nobles ejemplos de la poesía brasileña moderna, ejemplos numerosos. 
¿Cuándo, en efecto, las voces líricas de un país han sonado con tan denso y tenso acento de humanidad? ¿Y cuándo, al mismo tiempo, con tan sugestiva originalidad, en su estilización? Poetas anteriores a los que aquí estudiamos, Raymundo Correa, Teófilo Dias, Augusto de Lima, cuya obra no presenta ningún intento siquiera de estilización, ¿ son, acaso, más humanos que Tasso da Silveira, Jorge de Lima, Murillo Araújo, pongamos por ejemplo? El hombre primitivo, todo instinto, todo adivinación, supo ver la naturaleza como verdadero artista. En las cosas reflejó la intensidad con que tal o cual aspecto golpeó en su imaginación. Ya que en motivos americanos nos movemos, fácil es evocar cualquiera de las decoraciones indígenas precolombinas, en las que el instinto estético se expresa tan beliamente. $Y$ ya que, más especialmente, se estudia aquí un sector del arte brasileño, recordaré una espléndida obra de la cerámica uhengaiba, proveniente de la isla Pacoval, en la isla Marajó. (Esto requiere una breve acotación: Marajó, la más grande isla fluvial del mundo, tiene, en su centro, el lago Arary -o sea, "lago de las araras" - y en dicho lago se halla la isla Pacoval, de donde se han extraído, en grandes excavaciones, numerosos y bellos ejemplares de la alfarería nhengaiba, ya que en esa isla los indios efectuaban los entierros - en las interesantísimas igacabas o urnas funerarias.) Pues bien: en dicha cerámica, la decoración indígena representa un ave nocturna. ¿Cómo expresó el artista ese motivo? Dos ojos enormes, redondos, asustadores, como dos soles negros. En el ave nocturna, aterradora, el indio vió sólo la fosforescencia de los ojos. Lo demás ¿qué importa? Puesto que en la decoración no pudo -como hubiera sido posible en la poesía- expresar la estridencia del grito de aquella ave - nacurutú, huimara o acauán, tanto da-, fijó lo que más había herido su sensibilidad, suprimiendo o reduciendo a un plano secundario todo lo demás. $Y$ así, el artista moderno, en la nerviosa vida de hoy, se hermana estéticamente con el hombre primitivo, al ser, como él, un estilizador, si bien es cierto que a menudo esa estilización es el resultado de una densa cultura, de una larga experiencia, desconocidas por el indígena. Pero el arte realiza su milagro, y en la obra terminada - sean cuales fueren los caminos para ir a ella- los hombres fraternizan a través del tiempo y clel espacio. 


\section{Nativismo: vocablo brasileño}

Como constatación de la trascendencia que tiene el carácter nativo en la poesía del Brasil, es interesante señalar que el vocablo nativismo, como designación de una tendencia literaria, es un brasilerismo. Ya muchos años antes de que ese vocablo fuera conocido y usado en los países hispanoparlantes, to había empleado el poeta bahiano Mello Moraes Filho (1844-1919) en la página 110 de su libro Festas e tradições populares, editado por la librería Garnier, de París y Río. $Y$ aunque dicha obra no lleva fecha, se publicó sin duda a fines del siglo pasado. Además, en la página 325 del Almanaque Garnier correspondiente al año 1907 y publicado en Río, también se emplea ese vocablo, comentando precisamente las poesías de Mello Moraes Fitho. En cambio, en los países hispanoparlantes, la palabra nativismo se empezó a usar después de la gran guerra de 1914-19.

\section{Brasilidad}

¿Cómo definir el sentido lírico de la brasilidad? ¿Es, como algunos opinan, un latido de jungla, un deslumbre de sol, un desfile de mitos tupí-guaraníes, un alegre y triste resonar de tambores negros, en las más típicas calles de Bahía? Es todo eso, más la creciente civilización del país y su honda expresión espiritual, su noble vibración mística de pueblo eminentemente religioso. $\mathrm{Y}$ es también la alegría casi infantil de una región de vida fácil y multicolor. $Y$ es, unida a esa alegría, la saudade, sentimiento encerrado en un vocablo nacido en Portugal, pero que en el Brasil halló su más lindo y ancho sentido. Como bien afirma Benjamín de Garay, la palabra saudade "abarca en sí sola toda la escala graduada del sentimiento, porque ella permite expresar no sólo la tristeza de una despedida, la alegría de un recuerdo, la delicadeza de una emoción, la verdad de una esperanza, la nostalgia de la patria, sino también esa melancolía de la ausencia, la afección de una amistad, la fuerza de un vínculo, la sombra de una pena, la sensación de un afecto o la forma de un pensamiento imperecedero. Todo eso, y mucho más que eso, es saudade."

$\mathrm{Y}$ todo eso material y espiritual, sensual y místico, alma y naturaleza, sol y espíritu, jungla y urbe, alegría y saudade, todo eso 
es, en síntesis, lo que define una personalidad inconfundible, todo eso es, en sintesis, la brasilidad.

\section{Americanidad}

Y así, la brasilidad es una faceta - grande y bella- de la anericanidad. Bella y grande faceta, ya que el Brasil es uno de los países más americanos del Continente. Lo es por su color autóctono, por su vida intensa, su vigorosa individualidad; que sabe recibir inteligentemente las irradiaciones de la cultura universal, transformándolas y adaptándolas en su propio crisol. País bellamente americano, porque, amando el tesoro de su tradición sabe sin embargo no ser esclavo de ella, y se asoma a la vida con el optimismo y el brío de una sonrisa pura y virginal como un amanecer.

\section{Universalidad-Humanidad}

Ahora bien: estos poetas tan nativistas, tan americanos, ¿contrarían con su obra la ley estética que da mayor jerarquía a una obra cuanto mayor sea su universalidad? No. Ya hemos dicho que una de las características más salientes e interesantes de estos líricos reside en su denso y tenso acento humano. $Y$ puesto que son humanos - humanísimos-, han sabido, al captar los más nobles matices de brasilidad, unirlos a los de los sentimientos de valor duradero y universal. Su poesía es, así, una nota armoniosa en el concierto lírico del mundo.

\section{La Urbe, símbolo de una multiplicidad lírica}

Quizá, si se deseara buscar una imagen de la poesía brasileña, nada mejor que hermanarla a la belleza múltiple de Río de Janeiro. La riqueza y armonía de esa gran ciudad corresponde a la riqueza y armonía de su panorama lírico. Capital que sabe recibir comprensivamente los progresos de las grandes urbes de Europa, pero sin perder por ello su carácter brasileño y, por ende, americano. Ciudad donde la agreste presencia del matto fraterniza con la albura de los 
rascacielos, como en su poesía la nota selvática se enlaza con el ritmo arquitectónico, a la manera de Valéry. Ciudad de barrios aristocráticos : Laranjeiras, Copacabana, Ipanema, Botafogo, Flamengo, y de popularísimos suburbios multicolores: Meyer, Mangueira, Piedade, Cascadura. Asi, en la poesía, la expresión depuradísima de un esteticismo quintaesenciado se da la mano con el lirismo popular de una dulce humildad. Ciudad de alegría luminosa y de fina saudade; poesía de fina saudade y de luminosa alegría. Junto al ímpetu de una montaña, la serenidad de una laguna. $Y$ el goce dionisíaco alternando con la beatitud mística.

En Río - a pesar de un cosmopolitismo que no ha logrado ahogar el carácter nacional - se concentra la psicología brasileña, como en una esquina de Buenos Aires se fija - segín el ojo avizor de Scalabrini Ortiz - la psicología del porteño.

\section{La lucha por la nueva poesía}

Al terminar en 1918 la gran guerra iniciada cuatro años antes, el pensamiento universal, la vida universal y, en especial manera, el arte universal, sintieron el influjo de una muy acentuada renovación. En la poesía, ese remozamiento comenzó a expresarse de una manera amplia y viviente, entre los años 1920 y 22. Los nombres que deben quedar fijados al frente de esta noble lucha son, en el Brasil, los de Mario y Oswaldo de Andrade, Ronald de Carvalho, Graça Aranha, Tasso da Silveira, Villalobos, Andrade Muricy, Menotti del Picchia, Renato Almeida y otros. Ya en la poesía, en la novela, en la mísica, en la crítica, cada uno aportaba - como a fines del siglo XIX los simbolistas franceses- su colaboración, su creación, su faceta necesaria para el conjunto. Las dos ciudades más populosas del Brasil, Río y San Paulo, fueron, naturalmente, las que vibraron con mayor intensidad en esa lucha, siendo quizá San Paulo la que más se adelantó y destacó en tal sentido. Así lo afirmó Oswaldo de Andrade, el gran novelista de Condenado y poeta también, en su.magnífica conferencia sobre literatura brasileña, pronunciada en París, en la Sorbona, en mayo de 1923.

En San Paulo cantaba el entusiasmo juvenil de los nuevos grupos literarios: el "verde-amarillo", el "palo-Brasil", el de la "revolución del Anta”. En Río destacóse especialmente el noble grupo 
que con el sugestivo nombre de "Fiesta", encabezaban -y encabezan aún hoy, pues su vigor desafía los vaivenes de la moda y del tiempodos escritores de densa cultura y generoso espíritu: Tasso da Silveira y Andrade Muricy. E1 grupo "Fiesta" publicó, con título homónimo y en dos épocas, una de las mejores revistas literarias de América. La precedió la revista Klaxon de 16 páginas, que merece, en la historia de la literatura brasileña, un recuerdo afectuoso por lo que representó de lucha y de entusiasmo juveniles. Entre sus fundadores figuraba Menotti del Picchia, autor del celebrado libro Jucá-mulato - de quien hablaré más ađelante.

El brío renovador de San Paulo y Río de Janeiro se extendió, naturalmente, a todo el país, y en Cataguazes, en el vasto y rico Estado de Minas Geraes, el grupo llamado "verde" agitó su vivo afán revolucionario. Y más allá, en Pernambuco, y más allá en Pará, en la legendaria tierra amazónica, toda esa juventud lírica luchaba - según la afirmación de Aníbal Machado- "en la seguridad de que aún no sabía, quizá, lo que querían, pero sabían perfectamente lo que no querían".

En esta evolución entraban, sin duda, algunos elementos reflejos de las corrientes estéticas que acababan de triunfar en Europa. Oswaldo de Andrade relataba así, en su conferencia en la Sorbona, algunos aspectos de aquella lucha artística: "Manuel Bandeira y Menotti del Picchia toman su lugar junto a Mario de Andrade, que es atacado por los parnasianos y por los señores protocolares. Guilherme de Almeida, poeta muy apreciado por el público, se une al movimiento innovador. $Y$ el regreso de Europa, de Graça Aranha, da todavía más vivo interés al movimiento, por tratarse de uno de los literatos más respetados, académico, profesor de derecho, que vivió largamente en los grandes centros de civilización, y cuya influencia es profunda. Graça Aranha se adhiere inmediatamente a la generación constructiva. $\mathrm{Y}$ se llega a producir en San Paulo, bajo el patronato de Paulo Prado, sobrino y heredero de las cualidades aristocráticas e intelectuales de Eduardo Prado, una semana de arte moderno brasileño."

Es indudable también que, como afirma Oswaldo de Andrade más adelante, las influencias de Valery Larbaud, de Jules Romains y de Joseph Conrad no estuvieron ausentes en ese movimiento.

Conviene también recordar las palabras con que - poco antes de la citada conferencia de Oswaldo de Andrade- se expresó 
Coelho Netto, el formidable autor de Inmortalidad, en un reportaje que le hiciera Guillermo Estrella, en la capital del Brasil, a fines de 1922. Decía así Coelho Netto: "En lo que se refiere a la dirección que tomarán nuestras tendencias intelectuales, nada puedo predecir, pues nuestra actividad se halla en un período de juventud un poco confuso. Dudo, sin embargo, que nos encaminemos hacia la filosofía. Nuestro paso es demasiado rápido para que podamos detenernos a meditar. Nos hallamos en el momento de la creación poética, cantamos el himno de la marcha. Todo en nosotros es impulso y juventud, y cuando se me habla de poetas decadentes en América, eso me parece risible, absurdo."

\section{"El artista volvió a tener los ojos adolescentes y se encantó nuevamente con la vida"}

La bella afirmación que acabamos de reproducir, forma parte del manifiesto que el grupo "Fiesta" —encabezado, como hemos dicho, por Tasso de Silveira y Andrade Muricy- estampó en el primer número de su revista. Tiene enorme importancia en el estudio de la nueva poesía brasileña, porque en él está como condensado y coordinado lo más trascendente, vital y duradero de las luchas que la juventud brasileña, en el norte y en el sur, emprendió en su afán renovador. Por eso, transcribiremos íntegramente ese manifiesto, advirtiendo que su traducción española pertenece al poeta y ensayista paraguayo Leopoldo Ramos Giménez. Helo aquí:

Nosotros tenemos una visión clara de esta hora.

Sabemos que es de tumulto y de incertidumbre.

Es de confusión de valores

$y$ de victoria del arrivismo

y de grandes amenazas para el hombre.

Pero sabemos también que no es ésta la primera hora de inquietud y de agonía que vive la humanidad.

La humanidad danza su danza eterna en un viejo ritmo en dos tiempos.

Cuando todas las fuerzas interiores se equilibran, los gestos son luminosamente serenos. 
Y lo que en esos gestos parecía un esplendor supremo de belleza

o de verdad,

no era sino un efímero momento.

Es cuando salen a flor, de las profundidades del ser, ímpetus bruscos e imprevistos,

que traen la insatisfacción,

la angustia,

la fiebre,

y quiebran los compases armoniosos,

y hacen pensar, a los que se olvidaron de Dios,

que todo está perdido.

Y... en todo eso no hay sino ondas desconocidas de energía para la creación de un equilibrio nuevo

y de otra más alta serenidad.

Nosotros tenemos la comprensión nítida de este momento.

De este momento en el mundo

$y$ de este momento en el Brasil.

Vemos allá fuera o aquí dentro el rodar de los sentimientos en torbellino trágico.

$Y$ de las embestidas reivindicadoras

de los apetitos que se disfrazaban

$y$ ahora se desencadenan en furia.

Y oímos el suspiro de alivio

de la mediocridad finalmente desoprimida:

de la mediocridad, que aprovechando el desequilibrio

de un instante,

alzó también su voz en falsete

y llenó el aire de gestos desarticulados

y se proclamó vencedora

en la ingenua ilusión

de que las barreras que la contenían cayeron para siempre.

Pero vemos igualmente los espíritus legítimos en su puesto, inmutables.

Y entregamos el oído al llamado de alerta de las sentinas perdidas.

Y sentimos a flor del suelo el frémito de las corrientes

subterráneas, de fuerza viva, que serán captadas por la sabi-

duría divina en la hora próxima de las construcciones admirables. 
El arte es siempre el primero que habla para anunciar lo que vendrá.

E1 arte de este momento es un canto de alegría, una reiniciación de la esperanza, una promesa de esplendor.

Pasó el profundo desconsuelo romántico.

Pasó el estéril escepticismo parnasiano.

Pasó la angustia de las incertidumbres simbolistas.

E1 artista canta ahora la realidad total:

la del cuerpo y la del espíritu,

la de la naturaleza y la del sueño,

la del hombre y la de Dios.

Y la canta, porque la percibe y comprende

en toda su múltiple belleza,

en su profundidad e infinitud.

$Y$ por eso su canto

está hecho de inteligencia y de instinto

- porque también debe ser total-

y está hecho de ritmos libres

elásticos y ágiles como músculos de atletas,

veloces y altos como sutilísimos pensamientos;

$y$, sobre todo, palpitantes

del triunfo interior

que nace de las adivinaciones maravillosas...

El arte volvió a tener los ojos adolescentes

y se encantó nuevamente con la vida:

Todos los hombres lo acompañarán.

\section{Esta visión}

La visión que a continuación presentaremos al lector no es reflejo de ninguna antología o ensayo de otro autor. Su selección, como su presentación y coordinación, son, en el carácter sintético en que están desarrolladas, obra de un estudio entusiasta, trabajo personal, bastante arduo si se tiene en cuenta la labor delicada y paciente que representa -además de agrupar escritores cuyos libros, en muchos casos, no se hallan a la venta ni aun en el propio país- mantener el 
espíritu crítico en esa línea de imparcialidad y vigilancia tan difícil tratándose de escritores contemporáneos, es decir, con un prestigio muchas veces agrandado o disminuído por motivos ajenos al valor intrínseco de su obra.

Comenzaremos nuestra visión con la figura de Ronald de Carvalho, por considerar que es él quien con más gallardía representa el espíritu nuevo del Brasil, y quien más ampliamente abrió a las futuras generaciones las puertas de la joven poesía, que de manera tan considerable enriquece la literatura total de ese hermoso país.

Pero antes de referirnos a los módulos de la nueva lírica del Brasil, queremos recordar algunos nombres anteriores a ese movimiento, dignos de admiración por la calidad y personalidad de su obra. En la poesía popular: Paulo Setubal, cuyo libro Alma cabocla alcanzó una difusión extraordinaria, llegó realmente al corazón del pueblo; Catulio da Paixao Cearense, algo así como el Paul Fort del Brasil ; Carlos Magalhaes de Azeredo, autor de un noble poema titulado "Sinfonía evangélica"; Vicente de Carvalho, poeta paulista que fué muy admirado en su época; Cruz e Sousa y Alphonsus de Guimaraens, simbolistas magníficos; Augusto dos Anjos, atormentado baudelairiano; Amadeu de Amaral, parnasiano; Da Costa e Silva, sonetista admirable; Hermens Fontes, conceptual y colorista; Eduardo Guimaraens y Homero Prates, de un suntuoso simbolismo, y Martins Fontes, parnasiano, cuyos versos, impecables como los de Leconte de Lisle, tienen también la grandeza cósmica, el vigor sinfónico de Olavo Bilac, el mayor parnasiano del Brasil, el poeta de ese país más difundido en todo el resto de América.

SEGUNDA PARTE

\section{Ronald de Carvalho}

Aunque enfocaremos la figura de Ronald de Carvalho en su aspecto puramente lírico, debemos, sin embargo, dejar constancia de la jerarquía de su labor de crítico y ensayista, contenida especialmente en sus dos tomos de Esiudios brasileros y en su perfecta Historia de la literatura brasilera, obra modelo en su género, traducida a varios idiomas. Pero, a pesar de la nobleza de su prosa, es sin duda en su 
expresión poética donde reside la más auténtica y alta personalidad de este artista. Es en Luz gloriosa, su libro inicial, publicado en 1913, es en Poemas y sonetos, en Epigramas irónicos y sentimentales, y especialmente en Toda América, en ese magnífico poema continental, donde el vigoroso americanismo del hombre y el intenso lirismo del artista se hermanan armoniosamente. Traducido al inglés, francés e italiano, ese libro pasó a ser una obra clásica en la literatura brasileña. Si Santos Chocano no hubiera publicado, con anterioridad a Ronald de Carvalho, su libro Alma América, podría afirmarse que Toda América es, en el orden cronológico, el primer poema continental. Pero si no lo es en ese orden, to es en el estético. El libro del poeta peruano - a pesar de sus innegables valores - nos presenta una América cantada tal como lo haría muchas veces, no ya un americano, sino un español admirador de América. Hay en Chocano demasiada altisonancia, demasiado verbalismo, defectos propios de la época en que sus poemas fueron escritos. En cambio, Ronald supo adaptar las buenas conquistas de la poesía nueva, estilizando, clarificando y logrando ser poeta de acento fuerte, sin énfasis, epopéyico sin pesadez libresca. Sus poemas son imaginativos y proféticos. En lo que se refiere a la versificación, era convicción de este autor que "el poeta debía crear su ritmo libremente". Y también esto lo aparta de Chocano, que en Alma América cantó al Continente en ritmos clásicos (magüer ciertas innovaciones métricas, que, más que intentos de versos libres, son combinaciones de metros clásicos). En cambio, el ritmo de Carvalho es americanísimo, por su libertad, por su acento agreste y - a veces - de una rudeza elástica e hirviente que refleja bien ciertos aspectos de la patria colombina.

Ronald de Carvalho nació en Río de Janeiro, en 1893. Falleció trágicamente en su ciudad natal, el 15 de febrero de 1935, a los cuarenta y dos años de edad. Su muerte se produjo a consecuencias de las heridas recibidas en un accidente automovilístico. Era, a la sazón, secretario de la Presidencia de la República. El día anterior al desastre que le costó la vida, Ronald de Carvalho había sido nombrado -en una inolvidable elección pública promovida por el Diario da Noite - para suceder a Coelho Netto como "Príncipe de Prosistas Brasileños". Al afirmar que, aprobando ese simpático plebiscito, consideramos que el poeta supera al prosista, puede tenerse una idea de nuestra admiración por este valor del arte americano. 


\section{Jorge de Lima}

En cierta ocasión, llamamos a Jorge de Lima "el poeta de la brasilidad". Seguimos creyendo que es él, mejor que ningún otro, quien merece ese título. Tanto en sus poemas puramente descriptivos, como en los más recientes, de una augusta espiritualidad: si en aquéllos supo captar ampliamente el color y el sonido de lo que de más típico tiene su hermosa patria, en éstos encerró en ritmos las más delicadas palpitaciones del alma de ese Brasil tan profundamente cristiano.

Jorge de Lima publicó en 1920 XIV Alejandrinos, en 1925 Poemas y Nuevos Poemas. Sus dos poesías más populares son las tituladas "Bangué" y "Esa negra Fuló", poesías que, con su propio título, bautizaron un tomo aparecido en 1930. Una selección lírica editóse en 1932. Siguió a esta antología el tomo titulado Tiempo y Eternidad, tomo en que también aparecen composiciones del poeta Murillo Mendes, de quien hablaremos más adelante.

La túnica inconsútil, obra de Jorge de Lima publicada en 1938, es la que mejor define la nueva faceta de la poesía de este autor, faceta profundamente cristiana. Es indudable que para muchos críticos brasileños y extranjeros, de Lima está considerado como el mejor poeta contemporáneo del Brasil. Es de los más originales, de los más modernos (en la buena acepción del vocablo), de los más sinceros, de los más intensos.

Si en sus primeras poesías reveló una gran maestría en el arte de cincelar poemas de forma impecable, más tarde - en la época que corresponde a sus poemas "Bangué" y "Esa negra Fuló" - creó ritmos personalísimos, libres, musicales, en los que supo muchas veces interpretar, depurar y estilizar ciertos matices de la tonada folklórica. Quizá es en esta segunda fase de su lírica donde la brasilidad de Jorge de Lima se expresa más vivamente. En la mayor parte de tales poemas encontrará el lector bellas y auténticas imágenes del norte del Brasil, donde según afirma lindamente una canción popular, está el "Brasil brasilero". Allá en el norte, en el Estado de Algoas -uno de los que, a pesar de sus progresos, mejor conserva su matiz típico-, nació Jorge de Lima, en 1895. Es médico y actualmente reside en Río de Janeiro. Quien desee estudiar ampliamente la personalidad literaria de este escritor - autor, también, de varios ensayos 
muy interesantes y de algunas bellas novelas - debe recurrir al libro titulado La poesía de Jorge de Lima, por el crítico portugués Manuel Anselmo, libro editado en 1939 por la empresa gráfica de la Revista dos Tribunaes, de San Paulo, Brasil. Recientemente se publicó también un tomo de poemas de Jorge de Lima, con prefacio de Georges Bernanos, traducidos al español por J. Torres Oliveros y C. R. Arechavaleta. Dicha obra incluye preferentemente páginas que corresponden a la tercera fase lírica de Jorge de Lima, es decir, la profundamente subjetiva, de un cristianismo muy humano y con ciertos aspectos superrealistas en su expresión, fase que parece ser la preferida del propio autor.

\section{Tasso da Silveira}

Poeta y ensayista, Tasso da Silveira es uno de los más altos valores de la intelectualidad brasileña. En su obra, vasta y diversa, figuran libros fundamentales para el estudio de la literatura de su país, de la que Tasso da Silveira es un animador y divulgador entusiasta y erudito.

Sus obras sobre Romain Rolland, Jackson de Figueiredo, Darío Vellozo, bastarían - si no existiera su labor poética- para dar a su figura la autoridad crítica que con tanta justicia se le reconoce. Son también libros de ensayo, los titulados La iglesia silenciosa, Alegría creadora, Definición del modernismo brasileño, Caminos del espiritu, Espiritus-fuentes y El sagrado esfuerzo del hombre.

A la poesía ha llevado Tasso da Silveira - junto a sus naturales dotes líricas - un marcado acento espiritualista, que le destaca con relieves propios en el coro de sus colegas, que, generalmente -aun los más subjetivos-, no pueden dejar de dominarse por los elementos objetivos, por la sensual sugestión del opulento país en que les tocó en suerte vivir y cantar.

La poesía apretadamente espiritualista - con ciertos toques filosóficos- tiene sin duda arduos escollos, porque su carácter conceptual puede muchas veces disminuir la intensidad emotiva o la belleza imaginativa - dos virtudes inherentes del hecho poético. Pero Tasso da Silveira es tan poeta, que sabe aliar armoniosamente todos esos elementos, primando siempre la esencia lírica. De esta manera puede afirmarse que, en sus versos, el pensador no domina nunca al poeta. Es el poeta que da mayor riqueza, originalidad y valor humano a sus 
estados anímicos, infundiéndoles el latido trascendental de sus profundas meditaciones. Una de las más nobles características de la poesía de Tasso da Silveira está en su sentido heroico, espiritualísimo, en su exaltación. de los más puros valores de la vida, de los que es un animador entusiasta. Muchos de sus poemas tienen algo de sinfonía wagneriana, en su grandeza cósmica. Todo lo que el alma humana tiene de más fino y fuerte, profundo, alado y generoso, halla en este artista su amigo ferviente, su leal apóstol.

Debe agregarse también que Tasso es uno de los más caracterizados críticos brasileños. Sereno, culto, justo. De él hemos hablado al referirnos al grupo literario "Fiesta" y a la magnífica revista homónima. En la actualidad dirige Cuadernos de la hora presente, la. mejor revista cultural del Brasil y una de las mejores de América. A la vez que lleva al exterior las más altas expresiones del pensamiento brasileño, difunde y adapta a las necesidades de su patria las nıejores conquistas del pensamiento universal.

Los más bellos poemas de Tasso da Silveira están contenidos en sus libros titulados Hilo de agua, El alma heroica de los hombres, Cánticos del Cristo del Corcovado, Alegorías del hombre nuevo y Descubrimiento de la vida. Este notable escritor nació en 1895 en Curityba, capital del Estado de Paraná.

\section{Olegario Mariano}

Poeta de los más populares y queridos de su patria, Olegario Mariano se caracteriza por su intenso lirismo, su vibrante inspiración y la corrección de sus medios expresivos. Sin ser propiamente un poeta simbolista, lo más calificado de su obra posee cierto parentesco con muchas de las facetas primordiales de un Verlaine, de un Samain. Pero, al mismo tiempo, lo separa de ellos su acento más humano, su expresión más clara. Los une la sugestión musical, la vaguedad ensoñadora, aristocrática muy a menudo. Sin duda, la poesía de Mariano es menos quintaesenciada que la de los dos poetas ya citados.

A veces - pocas - desarrolla Mariano temas autóctonos - recordemos su magnífico poema dedicado a su nativa tierra pernambucana. Ha escrito sonetos que quedarán como modelos de perfección, sonetos de los más bellos de la literatura brasileña. Especial- 
mente en su libro Ultimas cigarras, publicado en 1920, hay, en tal sentido, páginas admirables. El poeta exalta en esas poesías el lirismo generoso de la cigarra frente a la avaricia de la hormiga, como el reverso de la popular y errónea fábula de La Fontaine. Quizá Ultimas cigarras sea el mejor libro de este artista, que se inició en 1911 con el poemario titulado Angelus, al que siguieron: en 1912, Sonetos, en 1916, Evangelio de la sombra y del silencio, y en 1920, Agua corriente. Además, en Ciudad maravillosa, pequeño libro editado en 1922, Olegario supo cantar con emoción algunos aspectos de Río, no tanto en su faz objetiva, cuanto en su lírica esencia de saudade. En este libro figuran páginas de las más logradas de este autor, gran conocedor de la poesía universal, que ha traducido al portugués, con fraternal comprensión, versos del gran poeta español Juan Ramón Jiménez.

Olegario Mariano, cuyo nombre completo es Olegario Mariano Carneiro da Cunha, nació en Recife, Pernambuco, en 1889. Es uno de los más destacados miembros de la Academia Brasilera de Letras.

\section{Murillo Araújo}

"Una poesía diáfana, intuitiva, integral. Sin preconceptos antiguos. Sin preconceptos modernos. Con el lenguaje total de los niños. Con el alma entera sonando en el timbre que Dios le dió." Así, con tan certeras palabras, ha sido definida la lírica de Murillo Araújo, escritor nacido en 1894 en el vasto y rico Estado de Minas Geraes y radicado desde hace años en Río de Janeiro. Muy joven, publicó su primer libro titulado Carillones, en 1917, poemario en que ya se advertía la presencia de un purísimo temperamento lírico. Obras posteriores fueron confirmando y ampliando esa impresión. Las tres colecciones de poemas que Murillo Araújo dió a la estampa después de Carillones son las siguientes: en 1921, La cindad de oro; en 1927, La iluminación de la vida, y en 1933, Los siete colores del cielo.

En los poemas de La ciudad de oro, Murillo supo cantar con emoción inspiradísima los más sutiles aspectos de la espléndida capital carioca. Destácase especialmente el poema titulado "Ciudad de pasado", en que Araújo realiza una muy bella estampa del Río colonial. 
En las páginas de La iluminación de la vida, este artista mostró nuevas facetas de su espíritu, estilizando más sus poemas, a la vez que les infundía una mayor densidad emocional. E1 título del poemario expresa muy bien el carácter de su lirismo, en el que los más finos y profundos matices de la vida aparecen como iluminados, transfigurados, por la emoción e inspiración del poeta, que sabe también acercarse a ciertos temas que - por su humildad, por su aspecto de episodio cotidiano - sólo saben mostrar su riqueza estética, su esencia lírica, cuando a ellos se aproxima un auténtico poeta, un Murillo Araújo, y los anima, los espiritualiza, los sublimiza con su sortilegio lírico. Esta misma virtud la hallamos en las páginas del libro Los siete colores del cielo, en las que poemas como el titulado "El nacimiento del poeta" revelan cómo un alto poeta sabe remozar los temas y ser original, puro y magnífico, cuando en la nota humilde, la música de imágenes de la vida, pone su sensibilidad, su sinceridad, su fraternización lírica, su vibración humana y estética.

\section{Mario de Andrade}

Habiéndose especializado en los estudios de la interesantísima música brasileña, Mario de Andrade es conocido sobre todo en ese aspecto; pero su obra de poeta, contenida en varios libros, es de valor fundamental en la historia literaria del Brasil, no sólo por su mérito intrínseco, sino también por lo que representa, en el movimiento lírico revolucionario que en su patria -como en toda Iberoamérica- puede fijarse entre los años de 1919 a 1923. En tal sentido, no se debe olvidar que Mario de Andrade fué uno de los más nobles luchadores y propagandistas de las nuevas conquistas de la lírica universal, adaptándolas a las necesidades y a la psicología de la lírica brasileña.

Fué combatido duramente por la crítica miope, que no comprendía la urgente necesidad de renovar las corrientes poéticas, ya demasiado aquietadas en el remanso suntuoso de Olavo Bilac y de sus imitadores. Pese a la marmórea perfección de sus estrofas, su opulenta inspiración y erudición y su lirismo vibrante, Bilac no podía ya seguir siendo el modelo de la nueva poesía brasileña, orientada hacia rutas más humanas y libres, menos preocupadas por la excesiva correc- 
ción del estilo y más interesadas en un trabajo sutil y personal de estilización.

Mario de Andrade, que en 1917 había publicado - con el pseudónimo de Mario Sobral- un tomo de versos titulado Hay una gota de sangre en cada poema, dió a la estampa en 1922, con su nombre verdadero, el poemario Panlicea desvariada, obra muy importante para todo el que desee estudiar la evolución de la lírica brasileña. Del carácter revolucionario del tomo Paulicea desvariada, da idea la afirmación de un crítico que calificaba a Mario de Andrade de "iconoclasta y constructor al mismo tiempo, ya que, sobre las ruinas de lo que destruía, levantaba su obra".

A nuestro juicio, es en las páginas del breve y jugoso tomo que en 1927 publicó Mario de Andrade, con el título de Clan del jabotí, donde se hallan los más hermosos, densos y originales poemas de este artista depuradísimo. El valor de renovación que tienen tales poemas, no ha hecho que con el correr de los años - como acontece con otras obras de mérito histórico- pierdan esas páginas su lirismo de vida fuerte, duradera. $Y$ es que junto a esos elementos "de lucha" (lucha generosa y valiente, agreguemos de paso), están aquellos humanos y líricos, substanciales e individuales, vivientes y eternos, que duplican el mérito de la obra.

\section{Manuel Bandeira}

Como Mario de Andrade, Mantel Bandeira representa, con su obra, una reacción contra la lírica excesivamente formalística, a veces altisonante, a veces débil, a menudo artificiosa, que se iba repitiendo demasiado.

Manuel Bandeira es un poeta auténticamente moderno y de una sensibilidad muy brasileña. Aunque en algunos de sus poemas - como verbi-gratia, su "Evocación de Recife"- ha reflejado objetivamente ciertos aspectos de su patria, en sus poesías subjetivas es donde, a nuestro parecer, se expresa mejor su denso y original lirismo. Es en esas páginas irónicas a veces, tristes muy a menudo, humanísimas siempre, donde hallamos la vibración de uno de los más interesantes y personales poetas brasileños, que ha ejercido gran influencia en las novísimas generaciones de su tierra. 
Una de las características más propias de Bandeira es ese tono sencillo y libre, como de conversación, que hallamos en lo más puro de su estética. Ese tono presentaría grandes peligros de prosaísmo para un temperamento que no tuviera la jerarquía lírica de Bandeira, quien ha sabido triunfar gallardamente creando tuna poesía que ennoblece matices humildes e inéditos de la vida cotidiana - alta virtud del arte contemporáneo-, huyendo siempre de todo énfasis, de todo verbalismo, en un gran anhelo de limpidez y sinceridad, perfectamente logrado. Unido a ese aspecto -el más importante y original en la lírica de Bandeira - puede afirmarse que, a pesar de su acento nacionalista, este poeta tiene a veces ciertas afinidades con Verlaine, Baudelaire y Heine, especialmente en su melancólico ironismo.

Nació Manuel Bandeira en Pernambuco, en 1886, e hizo su debut literario en 1917 con el tomo titulado La ceniza de las horas, muy bien recibido por la crítica. Una de sus obras más originales es la llamada Libertinaje, editada en 1930. Glosando algún poema de ese libro, el gran crítico brasileño Andrade Muricy afirmó que "Manuel Bandeira expresa enormes cosas en pocas palabras de refrenada exaltación".

\section{Gilka Machado}

Gilka da Costa Mello Machado — una de las más inspiradas poetisas, no sólo del Brasil, sino de América- nació en el Estado de Minas Geraes. Tiene a veces algunos matices que recuerdan a la Condesa de Noailles y los primeros poemas de Juana de Ibarbourou. Afinidades temperamentales, que en cada una de las tres artistas poseen sú carácter personal.

La poesía de Gilka Machado es de una opulencia imaginativa muy viva, de una gran vibración emocional. Puede afirmarse que su lirismo refleja bien la sensualidad del trópico, siendo, por ende, una de las voces más ardientemente brasileñas. Esa sensualidad finamente espiritualizada da a sus poemas un carácter de intensa humanidad. Por momentos, resuenan en su lírica acordes panteístas de gran pureza. Otras veces revela riqueza conceptual, que armoniza muy bien con la vehemente sensibilidad que caracteriza toda su obra. Lo más bello y representativo de su arte está encerrado en el tomo que, con el título de Poesías, publicó en 1918. Tanto en la sección titulada "Cristales partidos", como en "Estados de alma", pueden hallarse poemas de los 
más musicales y delicados de la lírica brasileña. Un fervoroso optimismo, un sentido vivo y alto de la Naturaleza, un temperamento poético desbordante, palpitan en todos sus poemas. En cuanto a las formas expresivas, pueden hallarse en la lírica de Gilka dos aspectos: el primero, en poemas breves y sonetos magníficamente burilados, a la manera de los parnasianos, pero con un rico contenido emocional de que aquéllos carecían; y el segundo, quizá más valioso, se refleja en poemas extensos, de forma libre, en los que el instinto musical de la artista combina ritmos en un sinfonismo complejo, que a veces tiene algo de la lujosa inspiración de Wagner. Por la hondura de su sensibilidad y la belleza de su expresión, Gilka Machado ocupa un lugar de preferencia en la lírica americana, junto a Juana de Ibarbourou, Gabriela Mistral y. Alfonsina Storni.

\section{Rosalina Coelho de Miller}

Espíritu cultisimo el de esta artista, que en 1921 quedó consagrada en el panorama lírico del Brasil con la publicación de su hermoso libro Rito pagano, premiado por la Academia Brasilera de Letras. Aun cuando en dicho tomo hay algunos magníficos sonetos dedicados a su patria - entre ellos, el titulado "Tierra de Santa Cruz", muy inspirado-, puede afirmarse que, en general, Rosalinda Coelho de Miller refleja en su arte el aspecto cosmopolita y refinado del espíritu carioca. Su delicada feminidad y su exquisita cultura la apartan de esa poesía - tan amiga de otros poetas- que capta matices del alma popular, que se nutre del humus de la tradición autóctona. Y de esa manera, agrega Rosalina una faceta a la admirable multiplicidad de la poesía total, en la que caben todos los aspectos nobles del arte. La exagerada afirmación de algunos críticos de que todos los líricos del Brasil son de un acentuado carácter nacionalista - afirmación que, sin duda, se hace a veces con cierto tono de reproche-, queda desvirtuada con la presencia de varios caracterizados poetas. Entre ellos figura Rosalina Coelho de Miller. Debe señalarse también, muy especialmente, el libro que esta autora publicó en 1927, con el título de El desencantado encantamiento. Aunque escrito en prosa, tal libro es la expresión de un alto lirismo. Admirable por su originalidad y su sensibilidad, su cultura y la elegancia de su estilo, El desencantado encantamiento merece ser traducido a varios idiomas y ampliamente 
difundido en todas partes, pues en él palpita el alma de la mujer moderna en el buen sentido de la palabra, mujer de ciudad superciviliza$\mathrm{da}$, que sabe reflejar meditaciones y emociones con encantadora armonía y con una gallarda nobleza, que se une a su deslumbrante riqueza conceptual.

\section{Cecilia Meirelles}

Es una de las grandes poetisas de América. Hasta hace poco, su nombre - tan admirado en su patria - no era muy conocido en los demás países del Continente. Pero puede afirmarse que actualmente es Cecilia Meirelles una de las figuras líricas del Brasil que más rápida y seguramente van irradiando su prestigio en los países hispanoparlantes. Aparte de su copiosa y depurada labor periodística, Cecilia Meirelles expresa su personalidad intelectual en tres aspectos: es una poetisa personal y finísima; es autora de varios encantadores libros para los niños, y es una erudita narradora de algunos de los más interesantes aspectos del folklore brasileño, especialmente del afro-brasileño. En tal sentido merece citarse su hermoso estudio titulado "Batuque, samba y macumba", publicado en Portugal en 1935. En breves páginas, realiza la autora una certera y completa explicación del origen y significado de estos tres bailes. Pero en la labor poética, es donde Cecilia Meirelles ha puesto lo más bello de su espíritu. Tanto en las páginas de su libro publicado en 1923 con el título de Nunca más, como sus Baladas para el Rey, de 1925, nos hallamos frente a una extraña y admirable individualidad lírica, fuerte y sutilísima a la vez. No son esos poemas de carácter objetivo, como acontece, en general, con la lírica de su patria. Al contrario: el más apretado subjetivismo, la más astral espiritualidad caracteriza ambos tomos, de una emoción y una nobleza musicalizadas en ritmos de los más puros y delicados de la lírica femenina americana. Es, aquí, cierta ensoñadora dulzura chopiniana; es, más allá, una quemante sombra que parece alargarse del corazón torturado de Baudelaire; allí es la balada leve y juguetona estilización de la tonada popular; es, siempre, la presencia de un altísimo y depuradísimo temperamento estético. En poemas posteriores, esta autora ha evolucionado hacia planos surrealistas, en los que su individualidad lírica se expresa con la misma intensidad de aquellos sus primeros poemas inolvidables. La obra más reciente de esta artista 
es el magnífico libro Viaje (1939), que en 1938 obtuvo el primer premio de Poesía de la Academia Brasilera de Letras.

\section{Guilherme de Almeida}

Como Olegario Mariano — con quien tiene algunas afinidades estéticas-, es Guilherme de Almeida un poeta esencialmente lírico, de suntuosa cultura, de gustos muy depurados, de gran sugestión expresiva. Y, como Olegario Mariano, se caracteriza porque, en general, falta en su obra el elemento autóctono. El Libro de Horas de Sor Dolorosa, que Guilherme de Almeida publicó en 1920, podría pasar, traducido al francés, por una obra de Rodenbach o de Maeterlinck - y éste no es, desde luego, un pequeño elogio de Guilherme de Almeida.

Nacido en Campinas - llamada, con toda justicia y poesía, "la ciudad de las golondrinas"-, Guilherme de Almeida cuenta en la actualidad algo más de cuarenta y cinco años de edad. Es uno de los poetas más "realizados" de su generación. Toda su labor se caracteriza por su severo eclecticismo, su armoniosa espiritualidad, su estilo siempre revelador de un temperamento cultísimo.

Muchos poemas de este autor pueden ponerse como ejemplo de lo más bello que en la lírica mística ha producido el Brasil. Otra característica que también hermana a Almeida con Mariano, es la que se refiere al aspecto puramente formal. Ambos poetas se destacan por el cultivo de ritmos que, en general, carecen de esa libertad, de esa elasticidad de otros poetas conterráneos, un Ronald de Carvalho, un Tasso da Silveira, un Jorge de Lima.

Tanto Almeida como Mariano son consumados artífices, que pulen sus poemas con fervoroso entusiasmo, sin que ello amengüe el brío vital, el latido emotivo, que en ambos poetas es muy intenso.

Guilherme de Almeida es, además, un espíritu de generosa actividad, de admirable dinamismo creador. Además de haber vertido al portugués, con gran conciencia, obras de Tagore y de Geraldy, ha realizado una vasta y muy digna labor crítica, que confirma la magistral erudición, el espíritu ecuánime y el exquisíto gusto estético de este escritor, cuya opinión es altamente apreciada. 


\section{Adelmar Tavares}

Pernambuco, por cuya Facultad de Derecho desfilaron valores tan altos como Joaquín Nabuco, Ruy Barbosa, Castro Alves y Tobías Barreto, contribuyó siempre ampliamente a la riqueza de la poesía brasileña. Son pernambucanos Manuel Bandeira y Olegario Mariano, de quienes ya hemos hablado, y otros poetas que comentaremos más adelante. También Adelmar Tavares es hijo de aquel bello y progresista Estado del Brasil, de albísimas playas, delicados monasterios coloniales, usinas trepidantes, cocoteros rumorosos.

Adelmar Tavares — que desde hace años reside en Río, formando parte de la Academia Brasilera de Letras- publicó su primer libro en la ciudad de Recife, en 1907 : un tomo de versos titulado Desencanto. A esta obra siguieron las que mencionaremos: Trovas y trovadores (Río, 1910), Luz de mis ojos (versos, 1911), La poesía de las guitarras (1917), Noche llena de estrellas (versos, 1925), La linda mentira (1926), Poesias, selección lírica, con nuevas producciones (1929), Trovas (versos, 1931), El camino enlunado (versos, 1937), y A la luz del altar (1934). Es especialmente en las páginas de El camino enlunado - cuya tercera edición se publicó en 1939- donde este artista pernambucano ha dado su esencia poética. Su emocionalidad vibrante y la corrección y armonía de su estilo se vierten ya en la cuarteta breve, sencilla y jugosa, de tono popular y fondo filosófico, ya en el poema burilado y profundo, revelando a veces, junto a la fineza de sus sentimientos, gran madurez de conceptos, que no aminora los valores líricos de su obra. Traduciremos a continuación una linda canción de Tavares:

Yo vi a la estrella de la mañana

tomar la forma de una mujer

y venir a bañarse en el agua del río...

Vi sus ojos verdísimos

y su cuerpo blanquísimo,

flotando en el agua como una flor...

Mas como entonces era muy niño, nadie en el hecho acreditó ...

- "Es que el niño soñó". 


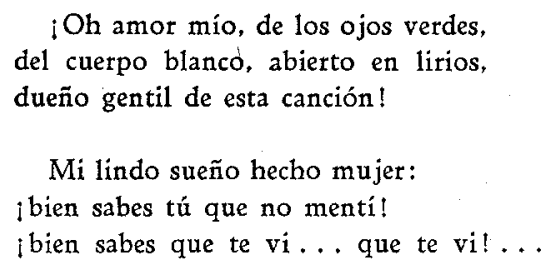

\section{Ribeiro Couto}

Este poeta, nacido en la ciudad marítima de Santos, en 1898, entró en el mundo literario por el pórtico de su lindo poemario titulado Jardin de las confidencias (1921). Si bien en obras posteriores Ribeiro Couto ha superado las virtudes líricas de aquellos versos, ampliando y ahondando su visión estética, las páginas de Jardin de las confidencias no deben ser olvidadas. Hay en ellas una dulzura tan auténticamente lírica, un acento tan claramente juvenil, tal cálida espontaneidad, que esos poemas poseen un ancho poder de simpatía y fraternización. Hacen evocar algunos de los más finos romances de Juan Ramón Jiménez.

La obra posterior de Couto ha cavado en el autoctonismo, y sus poemas inspirados en el noreste del Brasil son de los más originales, acertados y expresivos en ese tema. La labor lírica de este poeta paulista no está solamente en sus versos; se halla también en sus narraciones y, muy especialmente, en las incluídas en ese interesantísimo libro que se titula El crimen del estudiante Bautista (1922), en las impresiones de Río de Janeiro, coleccionadas en 1924 y en sus colaboraciones dispersas en un sinfín de periódicos y revistas. Espíritu muy humano, hondamente lírico, Ribeiro sabe hallar motivos poéticos en todos los temas, aun en aquellos que pudieran ser o parecer prosaicos. A veces, su visión está iluminada por un sutil y sano ironismo. Sus crónicas cariocas, a las que ya hemos hecho referencia, son verdaderos poemas en prosa. Poemas en prosa son también sus cuentos, de los más bellos que se han escrito en el Brasil. En su libro Poemetos de termura y de melancolía (1924), su poética presenta a veces ciertas afinidades con Maeterlinck y Verlaine, adaptadas a la sensibilidad brasileña. Hay en esos poemetos estrofas que por su sencillez, gracia y sensibilidad, no se olvidan nunca. 


\section{Casiano Ricardo}

"Martim-Cereré" es, en el folklore brasileño, uno de los nombres con que se designa a cierto pájaro pequeño, gracioso, de un color ceniciento obscuro. Dicho pajarito acompaña siempre a los viandantes, volando de rama en rama. La tradición dice que Martim-Cereré no es, en realidad, un pájaro, sino un negrito muy travieso, que gusta de extraviar a los peregrinos, y que luego huye riéndose. Lo cierto es que todos los niños del Brasil han sido arrullados con canciones en que se mencionaba al Martim-Cereré. Ese es también, en la literatura brasileña, el nombre del mejor libro de Casiano Ricardo, poeta de los más apreciados de su generación. Decía Saint-Pol-Roux que "la poesía, síntesis de todas las artes, es sabor, perfume, color, música y forma”. Este credo puede muy bien ser el de Casiano Ricardo, poeta objetivo y musical en grado sumo, de una jugosidad y de un colorido muy líricos en su rutilante sensualidad. La historia y el paisaje del Brasil -y, más especialmente, del Estado de San Paulo, de donde es nativo- han hallado en este artista a un animador entusiasta. Poetizar la historia de un país es una aventura arriesgada, por los declives al prosaísmo, al tono enfático, a la crónica pesada. Pero Casiano Ricardo ha sabido ver y esquivar esos declives, guiado por su instinto de auténtico poeta. Ningún prosaísmo existe en sus versos finos y sencillos, siempre cuajados de luces jubilosas; ningún énfasis en su voz $\tan$ brasileña, $\tan$ humana, $\tan$ familiar.

Entre lo más original y vigoroso de la obra de Casiano Ricardo figuran sus poemas - de tono épico- a los bandeirantes, aquellos esforzados expedicionarios que partían en caravanas al interior del Brasil, con el objeto, principalmente, de descubrir minas.

(Continuará)

Gastón Figueira, Montevideo, Uruguay. 
